\title{
Counteracting effects on free radicals and histological alterations induced by a fraction with casearins
}

\author{
ÉVERTON JOSÉ FERREIRA DE ARAÚJO ${ }^{1}$, GUILHERME ANTÔNIO LOPES DE OLIVEIRA ${ }^{1}$, \\ LÍVIA QUEIROZ DE SOUSA ${ }^{1}$, VANDERLAN DA SILVA BOLZANI ${ }^{2}$, ALBERTO JOSÉ CAVALHEIRO ${ }^{2}$, \\ ADRIANA DA ROCHA TOME ${ }^{3}$, ANA PAULA PERON ${ }^{4}$, ANDRÉ GONZAGA DOS SANTOS ${ }^{5}$, \\ ANTONIA MARIA DAS GRAÇAS LOPES CITÓ ${ }^{1}$, CLÁUDIA PESSOA ${ }^{6}$, \\ RIVELILSON MENDES DE FREITAS ${ }^{1}$ and PAULO MICHEL PINHEIRO FERREIRA ${ }^{1,7}$

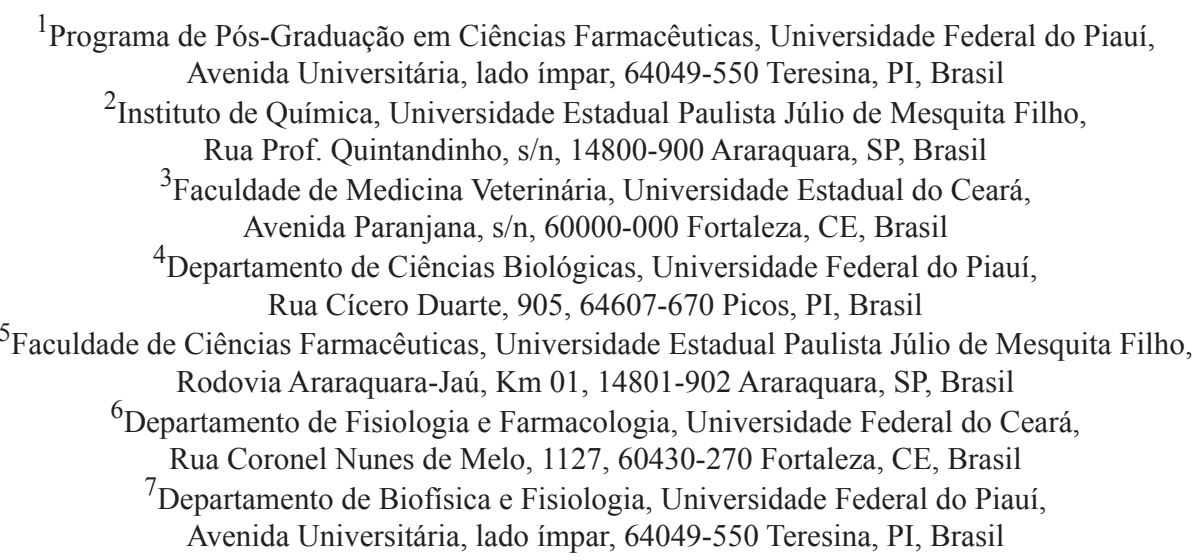

Manuscript received on February 26, 2015; accepted for publication on May 28, 2015

\begin{abstract}
Casearia sylvestris Swartz is a medicinal plant widely distributed in Brazil. It has anti-inflammatory, antiulcer and antitumor activities and is popularly used to treat snakebites, wounds, diarrhea, flu and chest colds. Its leaves are rich in oxygenated tricyclic cis-clerodane diterpenes, particulary casearins. Herein, we evaluated the antioxidant activities of a fraction with casearins (FC) isolated from C. sylvestris and histological changes on the central nervous system and livers of Mus musculus mice. Firstly, in vitro studies (0.9, 1.8, 3.6, 5.4 and $7.2 \mu \mathrm{g} / \mathrm{mL}$ ) revealed $\mathrm{EC}_{50}$ values of 3.7, 6.4 and $0.16 \mu \mathrm{g} / \mathrm{mL}$ for nitrite, hydroxyl radical and TBARS levels, respectively. Secondly, FC (2.5, 5, 10 and $25 \mathrm{mg} / \mathrm{kg} /$ day $)$ was intraperitoneally administered to Swiss mice for 7 consecutive days. Nitrite levels in the hippocampus $(26.2,27.3,30.2$ and $26.6 \mu \mathrm{M})$ and striatum $(26.3$, 25.4, 34.3 and $27.5 \mu \mathrm{M})$ increased in all treated animals $(\mathrm{P}<0.05)$. Lower doses dropped reduced glutathione, catalase and TBARS levels in the hippocampus and striatum. With the exception of this reduction in TBARS formation, FC displayed only in vitro antioxidant activity. Animals exhibited histological alterations suggestive of neurotoxicity and hepatotoxicity, indicating the need for precaution regarding the consumption of medicinal formulations based on Casearia sylvestris.
\end{abstract}

Key words: Clerodane diterpenes, Casearia sylvestris, antioxidant, morphological changes, toxicity.

Correspondence to: Paulo Michel Pinheiro Ferreira

E-mails: pmifepe@yahoo.com.br /

pmpf@ufpi.edu.br 


\section{INTRODUCTION}

Free radical is an atom, molecule or ion with short half-life, chemical instability and unpaired electrons. Free electrons that characterize the radical are usually in the atoms of oxygen, sulfur and nitrogen, culminating in the emergence of reactive species. Among these, there are the reactive oxygen species (ROS), reactive nitrogen species (RNS) from the decomposition of nitric oxide (NO) and sulfur derivatives (RSS) generated from the reaction of thiols with ROS (Carocho and Ferreira 2012, Alam et al. 2013).

Antioxidants, on the other hand, are substances that inhibit the oxidation process, maintaining the equilibrium of formation and removal of elements harmful to the body. Antioxidant defenses typically have enzymatic origins, particularly glutathione peroxidase (GPx), catalase (CAT) and superoxide dismutase (SOD), or no enzymatic bases as exogenous products such as vitamins (tocopherols and ascorbate), carotenoids, phenolic compounds, chelating agents and synthetic compounds. Enzymes prevent the production of free radicals while nonenzymatic antioxidants inhibit and block oxidative stress once they sequester reactive species (Rahman 2007, Alves et al. 2010, Halliwell 2011).

Antioxidant molecules derived from vegetables have biomedical potential, specially taking into consideration that oxidative stress directly participates in the genesis and progression of many diseases such as cancer, diabetes, cardiovascular and neurological illnesses (e.g., Alzheimer and Parkinson diseases) and aging process. With the increase of life expectancy, it becomes crucial to develop new strategies and therapies to combat chronic diseases (Ferreira et al. 2011, Krishnaiah 2011, Alam et al. 2013).

Neurodegenerative diseases can be derived from the action of reactive substances on neural pathways, causing damage to the nervous system homeostasis by lipid oxidation and neuronal apoptosis. Some studies have reported that once installed, neurodegenerative framework has a tendency to increase the content of free radicals and, consequently, lipid peroxidation levels due to the increased activity of membrane phospholipases. In other words, oxidative stress can both trigger neuronal disorder and even aggravate it, since free radicals are capable of damaging cell membranes (Pala and Gurkan 2008, Freitas 2009, Campêlo et al. 2011). In this context, plant species produce secondary metabolites belonging to different chemical groups such as alkaloids and cyanogenic glycosides and non-nitrogenous compounds, such as tannins, flavonoids, terpenes and anthocyanins that present antioxidant activity (Krishnaiah 2011, López-Alarcón and Denicola 2013).

Casearia sylvestris Swartz (Salicaceae) is a medicinal plant widely distributed in Brazil and known as "guaçatonga", "café silvestre", café-do-diabo" or "cafeeiro-do-mato". Ethanolic extracts and essential oil from their leaves have antiulcerogenic activity and reduce gastric volume without altering the stomach $\mathrm{pH}$, which corroborates their use on gastrointestinal disorders (Aboin et al. 1987, Basile et al. 1990, Esteves et al. 2005). Leaf water extracts show phospholipase $\mathrm{A}_{2}$ inhibitory activity that prevents damage effects on the muscular tissue after toxin inoculation (Borges et al. 2000, Borges et al. 2001, Cavalcante et al. 2007). The antimicrobial action against pathogens as fungi and bacteria, explains the uses to treat wounds, skin ulcerations, diarrhea, flu and chest colds by the Brazilian Karajá Indian tribe and natives from the Shipibo-Conibo tribe (Peru) (Carvalho et al. 1998, Oberlies et al. 2002, Mosaddik et al. 2004, Silva et al. 2006).

Analyses by nuclear magnetic resonance and X-ray spectroscopy elucidated structures of several compounds from $C$. sylvestris belonging to the class of diterpenoids including casearborins, caseargrewiins, casearlucins, casearinols, zuelanins, corymbolusins, caseamembrins, casearinones, intrapetacins, laetiaprocerins, and corymbotins. 
These molecules are reportedly unstable under acidic conditions and readily degrade to form the corresponding dialdehyde such as (-)-hardwickic acid. Many of these compounds had their bioassay done with different protocols and many have never been biologically tested. Pharmacological properties of the plant are mainly attributed to the clerodane diterpenes, secondary metabolites derived from isoprene units especially found in the leaves, with cicatrizing, anti-ophidian, antibacterial, antifungi, antiprotozoal, antiinflammatory and antiulcer activities (Mosaddik et al. 2004, Esteves et al. 2005, Mesquita et al. 2007, Cavalcante et al. 2007).

Additionally, most of these compouds have revealed remarkable in vitro and in vivo antitumoral activity on different histological human and murine cancer lines, such as Sarcoma 180, Ehrlich, Lewis lung cancer ascite, leukemias (HL-60, CEM, K-562), colon (HCT-8, HCT-116), breast (MDA-MB/231, Hs578-T, MX-1), melanoma (MDA/MB-435, B-16/ F10), prostate (PC-3, DU-145), ovarian (A-2780), lung (LX-1) and glioblastoma (SF-295) (Itokawa et al. 1990, Morita et al. 1991, Oberlies et al. 2002, Wang et al. 2009, Da Silva et al. 2009, Ferreira et al. 2010, Santos et al. 2010, Ferreira et al. 2011, 2014).

Based on these extensive ethnopharmacological traditions, this stydy evaluated the antioxidant activity of a fraction from $C$. sylvestris leaves using in vitro and in vivo experimental protocols and assessed histological changes on the central nervous system and on the liver of rodents.

\section{MATERIALS AND METHODS}

\section{EXTRACTION OF THE FRACTION WITH CASEARINS (FC)}

Leaves of C. sylvestris were collected at Parque Estadual Carlos Botelho (São Miguel Arcanjo, state of São Paulo State) by researchers of the Chemistry Institute of the São Paulo State University. Voucher specimens (AGS04, AGS05, AGS06, AGS13 and AGS19) were deposited at the Herbarium Maria Eneida P. Kaufmann of the Botanical Institute of São Paulo, Brazil. The ethanolic extract from the leaves and its fraction were obtained as described in Santos et al. (2010). Briefly, the extract was fractionated through a solid phase extraction using activated charcoal/silica gel $60-200 \mu \mathrm{M}(1: 1, \mathrm{~m} / \mathrm{m})$ as stationary phase and hexane/ethyl acetate (95:5, $\mathrm{v} / \mathrm{v}$ ), ethyl acetate and methanol as the mobile phase, providing three fractions, respectively. The second fraction obtained corresponds to the fraction with casearins (FC).

Clerodane diterpenes were identified at Núcleo de Bioensaios, Biossíntese e Ecofisiologia de Produtos Naturais (NuBBE), Institute of Chemistry, UNESP (Araraquara, São Paulo, Brazil) using high performance liquid chromatography (HPLC-DAD) as described in Claudino et al. (2013) and nuclear magnetic resonance considering literature data (Itokawa et al. 1990, Santos et al. 2010). These analyses showed FC presents $56.5 \%(\mathrm{mg} / \mathrm{g})$ of the total casearins, with caseargrewiin $\mathrm{F}$ and casearin $\mathrm{X}$ being the most present molecules (9.9 and 14.2\%, respectively) (Ferreira et al. 2014).

All in vitro subsequent studies were performed using growing concentrations of the FC $(0.9,1.8$, 3.6, 5.4 and $7.2 \mu \mathrm{g} / \mathrm{mL})$. All methods determined percentage reduction of the reactive species and the concentration of $\mathrm{FC}$ able to reduce in $50 \%$ the initial quantity of radicals (Effective Concentration - $\left.\mathrm{EC}_{50}\right)$. The standard antioxidant Trolox $(140 \mu \mathrm{g} /$ $\mathrm{mL}$ ) was used, since it is a water soluble synthetic analogue of tocopherol traditionally used as a reference in analyses of the antioxidant potential of compounds isolated from plant extracts and foods (Van Den Berg et al. 1999, Badarinath et al. 2010, López-Alarcón and Denicola 2013, Taira et al. 2015). The percentage of reduction of free radicals in in vitro reactions ( $\mathrm{R} \%$ ) was determined according to Reanmongkol et al. (1994): $\mathrm{R} \%=$ $100 \times\left(A_{c}-A_{T}\right) / A_{c}$, where $A_{c}$ is the absorbance of control, obtained from the reaction medium 
without sample and $\mathrm{A}_{\mathrm{T}}$ is the absorbance value of the tested substance (FC).

EVALUATION OF in vitro ANTIOXIDANT POTENTIAL ON Metabolite NitRite $\left(\mathrm{NO}_{2}{ }^{-}\right)$REMOVAL

The radical nitrite $\left(\mathrm{NO}_{2}{ }^{-}\right)$is obtained from the interaction of nitric oxide with oxygen and its formation is quantified by Griess reaction (Basu and Hazra 2006). Nitric oxide was first generated from the decomposition of sodium nitroprusside (SNP) in phosphate buffer $20 \mathrm{mM}$ (pH 7.4). The reaction medium $(1 \mathrm{~mL})$ in phosphate buffer containing SNP and FC was incubated at $37{ }^{\circ} \mathrm{C}$ for $1 \mathrm{~h}$. An aliquot was removed and mixed with $0.5 \mathrm{~mL}$ of Griess reagent. Chromophore absorbance was measured at $540 \mathrm{~nm}$. The inhibition of nitrite production was quantified comparing absorbance of controls (sodium nitroprusside $10 \mathrm{mM}$ and vehicle) and results were expressed as perceptual of nitrite formed by isolated SNP.

\section{EVALUATION OF in vitro ANTIOXIDANT POTENTIAL ON}

REMOVAL OF HYDROXYL RADICAL $(\bullet \mathrm{OH})$

The formation of hydroxyl radical $(\cdot \mathrm{OH})$ by the Fenton reaction was quantified using the oxidative degradation of 2-deoxyribose to malonaldehyde (MDA), which reacts with thiobarbituric acid (TBA) (Lopes et al. 1999). Reactions were initiated by the addition of ferrous sulphate $\left(\mathrm{FeSO}_{4}\right) 6 \mathrm{mM}$ in solutions containing 2-deoxyribose $5 \mathrm{mM}$, $\mathrm{H}_{2} \mathrm{O}_{2} 100 \mathrm{mM}$ and phosphate buffer $20 \mathrm{mM}$ in $\mathrm{pH}$ 7.2. To measure the antioxidant activity byt the removing of the hydroxyl radical, different concentrations of the FC were added to the system before the $\mathrm{FeSO}_{4}$ addition. After $15 \mathrm{~min}$ at room temperature, reactions were blocked by phosphoric acid $4 \%(\mathrm{v} / \mathrm{v})$ followed by TBA $(1 \% \mathrm{w} / \mathrm{v}$ in $\mathrm{NaOH} 50 \mathrm{mM})$. The solutions were heated for $15 \mathrm{~min}$ at $95{ }^{\circ} \mathrm{C}$ and cooled to room temperature. Absorbances were measured at 532 $\mathrm{nm}$ and results were expressed as a function of the 2-deoxyribose degradation.
EVALUATION OF in vitro ANTIOXIDANT POTENTIAL ON THIOBARBITURIC ACID REACTIVE SUBSTANCES (TBARS) REMOVAL

This test is used to quantify lipid peroxidation (Esterbauer and Cheeseman 1990) was adapted to determine the antioxidant capacity of the FC using homogenized egg yolk as a substrate rich in lipids (Guimarães et al. 2010). Egg yolk was briefly homogenized $(1 \% \mathrm{w} / \mathrm{v})$ in phosphate buffer $20 \mathrm{mM}$ (pH 7.4). Afterwards, $1 \mathrm{~mL}$ of the homogenate was sonicated and $0.1 \mathrm{~mL}$ of $\mathrm{FC}$ was added. Lipid peroxidation was induced by adding $0.1 \mathrm{~mL}$ of 2,2-azo-bis-(2-methylpropionamidine)dihydrochloride (AAPH) 0.12M. Only vehicle was added to the control group (DMSO 4\%). Reactions were performed for $30 \mathrm{~min}$ at $37^{\circ} \mathrm{C}$. After cooling, samples $(0.5 \mathrm{~mL})$ were centrifuged in $0.5 \mathrm{~mL}$ of trichloroacetic acid (15\%) at $1200 \mathrm{rpm}$ for $10 \mathrm{~min}$. An aliquot of $0.5 \mathrm{~mL}$ of supernatant was mixed with $0.5 \mathrm{~mL}$ TBA $0.67 \%$ and heated at $95{ }^{\circ} \mathrm{C}$ for $30 \mathrm{~min}$. Absorbances were measured at $532 \mathrm{~nm}$ and results were expressed as percentage of TBARS formed only by isolated AAPH.

\section{In vivo ANTIOXIDANT EVALUATION}

To evaluate in vivo antioxidant activity, adult male Swiss mice (Mus musculus) with 25-30 g were obtained from the animal facilities of the Federal University of Piauí. They were kept in wellventilated cages (Alesco, São Paulo) under standard conditions of light (12 h with alternative day and night cycles), temperature $\left(24 \pm 1{ }^{\circ} \mathrm{C}\right)$ and were housed with access to commercial rodent stock diet (Nutrilabor, São Paulo, Brazil) and water ad libitum. The investigational protocols were approved by the local Ethical Committee on Animal Research (Process No. 0102/2011) and are in accordance with the national (Colégio Brasileiro de Experimentação Animal - COBEA) and international standard on the care and use of experimental laboratory animals (EEC Directive of 1986, 86/609/EEC). 
The fraction enriched in casearins (FC) was previously solubilized in DMSO 4\% and intraperitoneally administered at doses of 2.5, 5, 10 and $25 \mathrm{mg} / \mathrm{kg} /$ day for 7 days ( $\mathrm{n}=9$ animals/group). Negative and positive controls were treated with DMSO 4\% and ascorbic acid (AA, $250 \mathrm{mg} / \mathrm{kg} /$ day) (Sigma Aldrich), respectively.

Seven treated animals from each group were randomly decapitated without anesthesia, their brains were dissected in ice and brain homogenates at $10 \%(\mathrm{w} / \mathrm{v})$ were prepared to measure protein concentration (Lowry et al. 1951), lipid peroxidation levels, nitrite ion and glutathione reduced (GSH) and catalase (CAT) in the hippocampus and striatum of the rodents.

For histological analysis, the brains of the remaining animals of each group were fixed in formalin $10 \%$ during $72 \mathrm{~h}$. Sagittal cuts of $1 \mathrm{mM}$ from preliminary incision close to the brains' mammillary bodies were obtained. To examine morphological changes by light microscopy (Olympus, Tokyo, Japan) at magnification of 400X, small pieces were processed, embedded in paraffin and 3-5 $\mu \mathrm{M}$ thick sections were prepared and stained with hematoxylin-eosin. Brain areas were observed and classified according to the Atlas of Paxinos and Watson (1986).

Determination of lipid peroxidation and nitrite ion levels in the hippocampus and striatum

Levels of reactive substances to the thiobarbituric acid (TBARS) were assessed to determine lipid peroxidation (Draper and Hadley 1990). Butanol phase was spectrophotometrically analyzed at $535 \mathrm{~nm}$. Results were expressed as nmoles of malondialdehyde (MDA)/g of homogenate.

Nitrite content in homogenates was based on the Griess reaction (Green et al. 1981). Briefly, $500 \mu \mathrm{L}$ of the sample were incubated with $500 \mu \mathrm{L}$ of Griess reagent at room temperature for $10 \mathrm{~min}$ followed by absorbance measument at $550 \mathrm{~nm}$. Results were expressed in $\mu \mathrm{M}$.
Determination of reduced glutathione (GSH) and catalase in the hippocampus and striatum

GSH concentration was performed with Ellman's reagent, 2-nitrobenzoic acid (DTNB) with free thiol, originating a mixed disulfide plus a 2-nitro-5-thiobenzoic (Sedlak and Linsay 1988). Homogenates $10 \%(\mathrm{w} / \mathrm{v})$ were prepared in EDTA $0.02 \mathrm{M}$. Then, they were centrifuged at $3000 \mathrm{rpm}$ for $15 \mathrm{~min}$. The removal of $400 \mu \mathrm{L}$ of the supernatant was carried out and $800 \mu \mathrm{L}$ of Tris- $\mathrm{HCl}$ buffer $0.4 \mathrm{M}, \mathrm{pH} 8.9$ and $20 \mu \mathrm{L}$ of the DTNB $0.01 \mathrm{M}$ were added. After $60 \mathrm{~s}$ of reaction, samples were read at $412 \mathrm{~nm}$. Results were expressed in $\mathrm{U} / \mu \mathrm{g}$ of protein.

Catalase activity was measured based on the rate of $\mathrm{O}_{2}$ and $\mathrm{H}_{2} \mathrm{O}$ production (Chance and Maehly 1955). The reaction medium was prepared with $\mathrm{H}_{2} \mathrm{O}_{2}(18 \mathrm{~mL})$, Tris- $\mathrm{HCl} 1 \mathrm{M}$, EDTA $5 \mathrm{mM}$ pH 8.0 (1.0 mL) and Milli-Q $\mathrm{H}_{2} \mathrm{O}(0.8 \mathrm{~mL})$. Subsequently, $940 \mu \mathrm{L}$ of reaction medium and $60 \mu \mathrm{L}$ of the homogenate from each organ were placed in quartz cuvette and read at $230 \mathrm{~nm}$ after $6 \mathrm{~min}$ at $37{ }^{\circ} \mathrm{C}$. Results were expressed in U/mg of protein.

\section{STATISTICAL ANALYSIS}

In order to determine differences, data were compared by one-way analysis of variance (ANOVA) followed by the Newman-Keuls test $(\mathrm{P}<0.05)$. In vitro studies were carried out in triplicate and represented independent biological evaluations. The concentration able to reduce $50 \%$ of the reactive species $\left(\mathrm{EC}_{50}\right)$ was calculated from the graphs of R\% with GraphPad Prism ${ }^{\circledR}$ software.

\section{RESULTS}

Herein, we performed in vitro and in vivo studies in order to demonstrate the antioxidant activity of the FC from $C$. sylvetris leaves against different reactive species that cause oxidative stress. This study was carried out using a fraction composed by a mixture of casearins since this represents the most folk approach in etnopharmacological uses by Brazilian population. Moreover, it is likely 
that distinct bioactive terpenoids may jointly or independently contribute to biological effects (Wattenberg 1985, Ferreira et al. 2011, Kumbhare et al. 2012).

Nitrite radical scavenging was performed by the method of Griess. Outcomes showed that there was a significant and progressive reduction in nitrite production with the increase of FC concentration $(0.9,1.8,3.6,5.4$ and $7.2 \mu \mathrm{g} / \mathrm{mL})$ (26.2, 30.4, 38.2, 43.7 and $50 \%$, respectively) $(\mathrm{P}<0.05$, Fig. 1). Trolox $(140 \mu \mathrm{g} / \mathrm{mL})$, a reference antioxidant drug, reduced production of nitrite in $59.8 \%$. The $\mathrm{EC}_{50}$ value of $3.7(2.8-4.9) \mu \mathrm{g} / \mathrm{mL}$ was capable of reducing $50 \%$ of nitrite production.

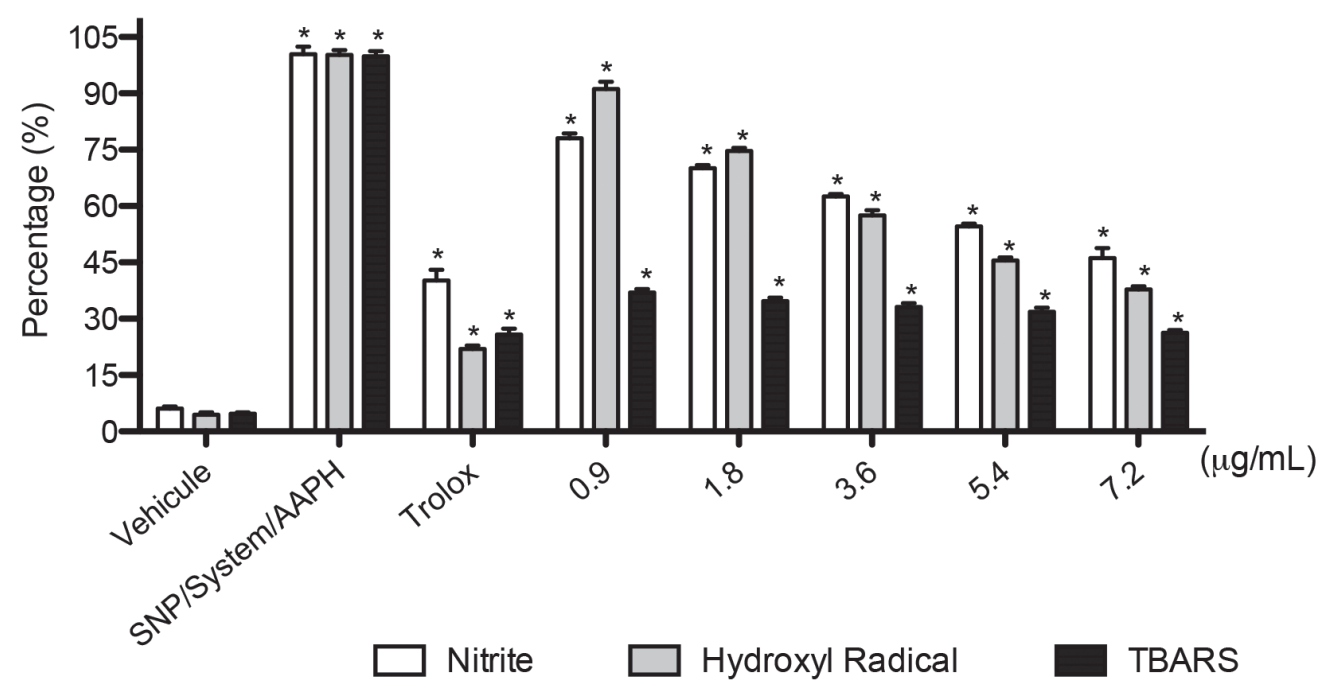

Figure 1 - In vitro effects of the Fraction with Casearins (FC) on the removal of the metabolite nitrite (nitrite production induced by sodium nitroprussiate, SNP), hydroxyl radical (2-deoxyribose degradation) and production of reactive substances to thiobarbituric acid (TBARS levels induced by 2,2'-azobis [2-methylpropionamidine] dihydrochloride, AAPH). Trolox $(140 \mu \mathrm{g} / \mathrm{mL})$ was used as standard antioxidant. Values are mean \pm S.E.M. of values for in vitro inhibition $(\mathrm{n}=5$ experiments in duplicate). ${ }^{*} \mathrm{P}<0.05$ compared to respective reaction medium by ANOVA followed by Student-Neuman-Keuls.

Concerning the formation of hydroxyl radical, all concentrations of the $\mathrm{FC}(0.9,1.8,3.6,5.4$ and $7.2 \mu \mathrm{g} / \mathrm{mL}$ ) significantly reduced free radical generation in relation to the reaction media, with a reduction of $10.5,23.9,42.7,54.5$ and $61.6 \%$, respectively, while Trolox promoted a reduction of $78.1 \%$ in relation to the system $(\mathrm{P}<0.05$, Fig. 1). Similarly, in vitro determination revelaed an $\mathrm{EC}_{50}$ of $6.4(5.7-7.3) \mu \mathrm{g} / \mathrm{mL}$ against hydroxyl radical formation.

Lipid peroxidation studies with FC (0.9, 1.8, 3.6, 5.4 and $7.2 \mu \mathrm{g} / \mathrm{mL}$ ) showed a significant reduction in TBARS generation compared to the AAPH (65.1, 66.7, 67.6, 69.4 and $72.4 \%$, respectively) ( $\mathrm{P}<0.05)$. Trolox caused a $74.1 \%$ of decrease in TBARS production (Fig. 1). Again, FC exhibited a potent antioxidant capacity, with $\mathrm{EC}_{50}$ of $0.16(0.07-0.39) \mu \mathrm{g} / \mathrm{mL}$.

Table I describes lipid peroxidation and nitrite concentrations in the hippocampus and striatum of FC-treated mice for 7 days. It was noted that FC reduced TBARS formation in hippocampus at lower doses $(59.9 \pm 1.5,57.4 \pm 1.4$ and $60.7 \pm 0.7 \mathrm{nmol}$ of MDA/g homogenate for 2.5, 5 and $10 \mathrm{mg} / \mathrm{kg} / \mathrm{day}$, respectively) $(\mathrm{P}<0.05)$, though in higher doses $(25$ $\mathrm{mg} / \mathrm{kg} /$ day) no alterations in TBARS levels have been detected $(\mathrm{P}>0.05)$ when compared to the negative control $(68.7 \pm 1.4 \mathrm{nmol})$. Only the dose 
of $5 \mathrm{mg} / \mathrm{kg} /$ day significantly decreased TBARS formation in the striatum $(5.5 \pm 1.6 \mathrm{nmol})$. On the other hand, striatum $(26.3 \pm 1.3,25.4 \pm 0.7,34.3$ \pm 2.4 and $27.5 \pm 1.4 \mu \mathrm{M})$ and hippocampus $(26.2$ $\pm 2.7,27.3 \pm 0.4,30.2 \pm 2.1$ and $26.6 \pm 1.6 \mu \mathrm{M}$ ) nitrite levels increased in all FC-treated groups in comparison with negative $(11.3 \pm 0.4$ and 11.4 $\pm 0.6 \mu \mathrm{M})$ and positive $(8.1 \pm 0.3$ and $7.9 \pm 0.4$ $\mu \mathrm{M}$ ) controls (for FC 2.5, 5, 10 and $25 \mathrm{mg} / \mathrm{kg} /$ day, DMSO $4 \%$ and AA, respectively $(\mathrm{P}<0.05)$.

TABLE I

Determination of the lipid peroxidation (TBARS), nitrite, GSH and catalase levels in the hippocampus and striatum of mice intraperitoneally treated with a Fraction with Casearins (FC) extracted from Casearia sylvestris leaves at doses of $2.5,5,10$ and $25 \mathrm{mg} / \mathrm{kg} /$ day during 7 days. Negative and positive controls were treated with DMSO $4 \%$ (vehicle) and AA $(250 \mathrm{mg} / \mathrm{kg} / \mathrm{day})$, respectively.

\begin{tabular}{|c|c|c|c|c|c|c|c|c|}
\hline \multirow{2}{*}{$\begin{array}{l}\text { Group } \\
\text { (mg/kg/ } \\
\text { day) }\end{array}$} & \multicolumn{2}{|c|}{$\begin{array}{c}\text { TBARS } \\
\text { (nmol of MDA/g } \\
\text { homogenate) }\end{array}$} & \multicolumn{2}{|c|}{$\begin{array}{l}\text { Nitrite } \\
(\mu \mathrm{M})\end{array}$} & \multicolumn{2}{|c|}{$\begin{array}{c}\text { GSH } \\
(\mathrm{U} / \mu \mathrm{g} \text { of protein) }\end{array}$} & \multicolumn{2}{|c|}{$\begin{array}{c}\text { Catalase } \\
(\mathrm{U} / \mu \mathrm{g} \text { of protein) }\end{array}$} \\
\hline & Hippocampus & Striatum & Hippocampus & Striatum & Hippocampus & Striatum & Hippocampus & Striatum \\
\hline Vehicle & $68.7 \pm 1.4$ & $62.9 \pm 1.9$ & $11.4 \pm 0.6$ & $11.3 \pm 0.4$ & $1.6 \pm 0.2$ & $1.5 \pm 0.1$ & $9.9 \pm 0.7$ & $10.9 \pm 0.9$ \\
\hline AA $(250)$ & $43.1 \pm 1.9^{*}$ & $47.6 \pm 1.7^{*}$ & $7.9 \pm 0.4$ & $8.1 \pm 0.3$ & $1.2 \pm 0.1$ & $1.8 \pm 0.1$ & $13.6 \pm 0.4^{*}$ & $13.1 \pm 0.4^{*}$ \\
\hline$\Xi \bigcirc 2.5$ & $59.9 \pm 1.5^{*}$ & $62.1 \pm 1.3$ & $26.2 \pm 2.7^{*}$ & $26.3 \pm 1.3^{*}$ & $1.0 \pm 0.3^{*}$ & $0.8 \pm 0.2^{*}$ & $4.3 \pm 0.6^{*}$ & $5.7 \pm 0.9 *$ \\
\hline$=5$ & $57.4 \pm 1.4^{*}$ & $53.5 \pm 1.6^{*}$ & $27.3 \pm 0.4^{*}$ & $25.4 \pm 0.7^{*}$ & $0.7 \pm 0.1^{*}$ & $1.0 \pm 0.1^{*}$ & $6.2 \pm 0.4^{*}$ & $6.3 \pm 0.5^{*}$ \\
\hline 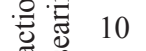 & $60.7 \pm 0.7^{*}$ & $60.8 \pm 0.6$ & $30.2 \pm 2.1^{*}$ & $34.3 \pm 2.4^{*}$ & $0.7 \pm 0.1^{*}$ & $1.3 \pm 0.1$ & $8.4 \pm 0.7$ & $8.4 \pm 0.7$ \\
\hline 式 25 & $69.8 \pm 1.7$ & $66.7 \pm 1.8$ & $26.6 \pm 1.6^{*}$ & $27.5 \pm 1.4^{*}$ & $0.9 \pm 0.2^{*}$ & $1.3 \pm 0.1$ & $9.4 \pm 0.4$ & $8.9 \pm 0.6$ \\
\hline
\end{tabular}

Results were expressed as mean \pm S.E.M. ( $n=9$ animals/group). TBARS, thiobarbituric acid reactive substances; GSH, reduced glutathione; AA, ascorbic acid.

$* \mathrm{P}<0.05$ compared with negative control by ANOVA followed by Student-Neuman-Keuls.

Catalase and GSH levels showed differences after exposure to FC and did not follow a typical outcome for a substance with in vivo antioxidant properties (Table I). So, while lower doses (2.5 and $5 \mathrm{mg} / \mathrm{kg} /$ day) dropped GSH and catalase activities in hippocampus $[(1.0 \pm 0.3$ and $0.7 \pm 0.1 \mathrm{U} / \mu \mathrm{g}$ of protein) and $(4.3 \pm 0.6$ and $6.2 \pm 0.4 \mathrm{U} / \mu \mathrm{g})]$ and in the striatum $[(0.8 \pm 0.2$ and $1.0 \pm 0.1 \mathrm{U} / \mu \mathrm{g})$ and $(5.7 \pm 0.9$ and $6.3 \pm 0.5 \mathrm{U} / \mu \mathrm{g})]$, respectively $(\mathrm{P}<$ $0.05)$, higher doses (10 and $25 \mathrm{mg} / \mathrm{kg} /$ day) did not alter GSH and catalase levels $(\mathrm{P}>0.05)$ in these brain areas in comparison with vehicle group [(1.6 \pm 0.2 and $1.5 \pm 0.1 \mathrm{U} / \mu \mathrm{g})$ and $(9.9 \pm 0.7$ and 10.9 $\pm 0.9 \mathrm{U} / \mu \mathrm{g})]$. However, these findings were lower than those in AA-treated animals $[(1.2 \pm 0.1$ and $1.8 \pm 0.1 \mathrm{U} / \mu \mathrm{g})$ and $(13.6 \pm 0.4$ and $13.1 \pm 0.4 \mathrm{U} /$ $\mu \mathrm{g})](\mathrm{P}<0.05)$.
Histological analyses revealed changes in the hippocampus such as nuclear vacuolization, pyknotic nuclei and hyperchromasia of the nuclear material at lower doses ( 2.5 and $5 \mathrm{mg} / \mathrm{kg} / \mathrm{day}$, Fig. $2 \mathrm{~b}$ and $2 \mathrm{c}$ ). In addition, there was a slight vascular congestion in the negative control group (Fig. 2d and 2e) and an absence of pathological alterations in the other groups, which exhibited homogeneous neurons and central nucleoli. Neither leucocyte infiltration nor intense tissue damage, such necrosis, were detected.

Morphological alterations in the striatum of FCtreated mice are described in Figure 3. At lower doses ( 2.5 and $5 \mathrm{mg} / \mathrm{kg} /$ day, Fig. $4 \mathrm{~b}$ and $4 \mathrm{c}$, respectively) disorganization of axons was observed, but normal tissue strias were seen in the other groups. Areas of necrosis or cellular infiltration were not detected. 

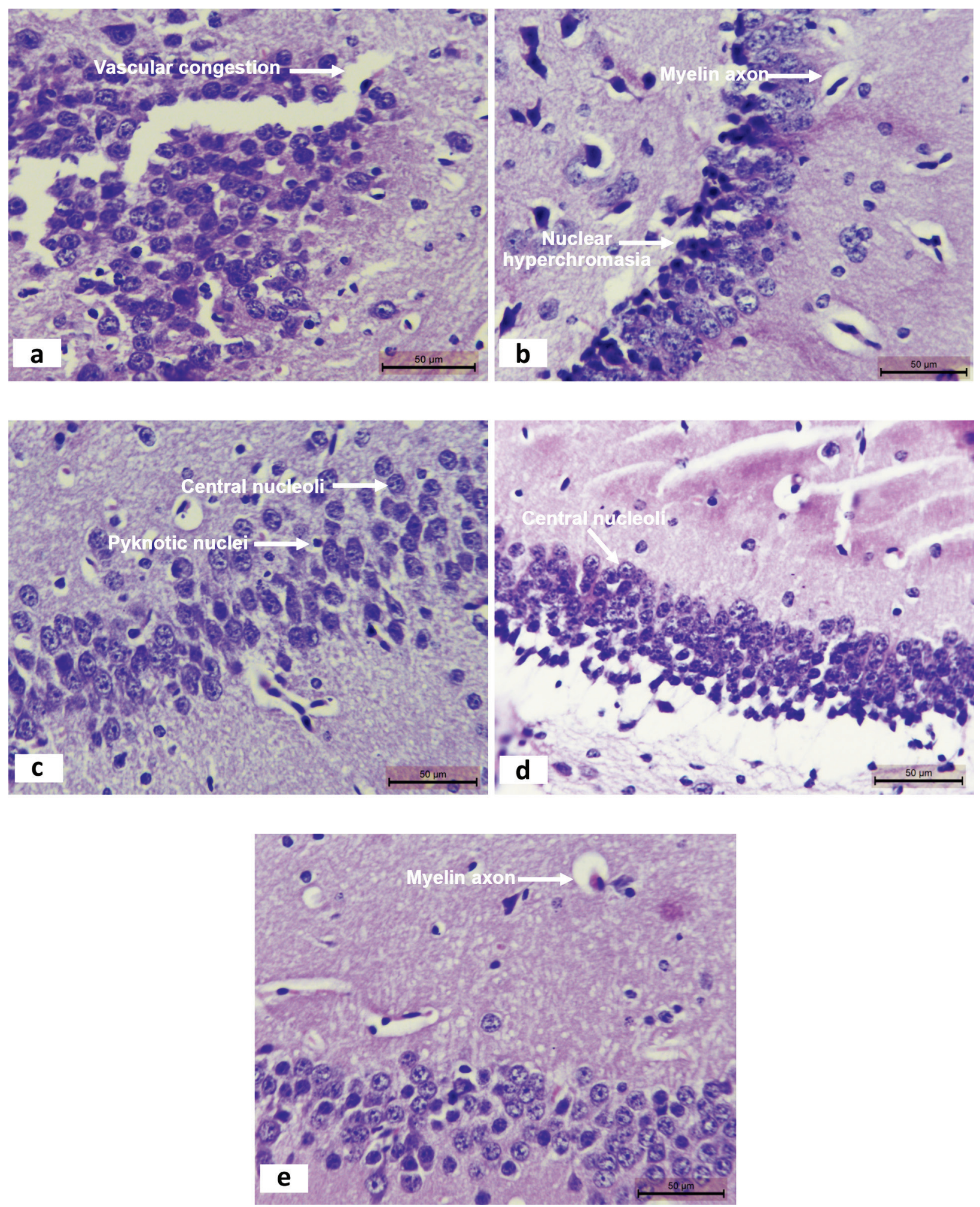

Figure 2 - Histological analyzes in hippocampus of mice intraperitoneally treated with a fraction with casearins extracted from Casearia sylvestris leaves at doses of 2.5 (b), 5 (c), 10 (d) and $25 \mathrm{mg} / \mathrm{kg} /$ day (e) during 7 days. Negative control (a) received DMSO 4\%. Hematoxylin-eosin staining. Magnification, 400x. Scale bar $=50 \mu \mathrm{M}$. 

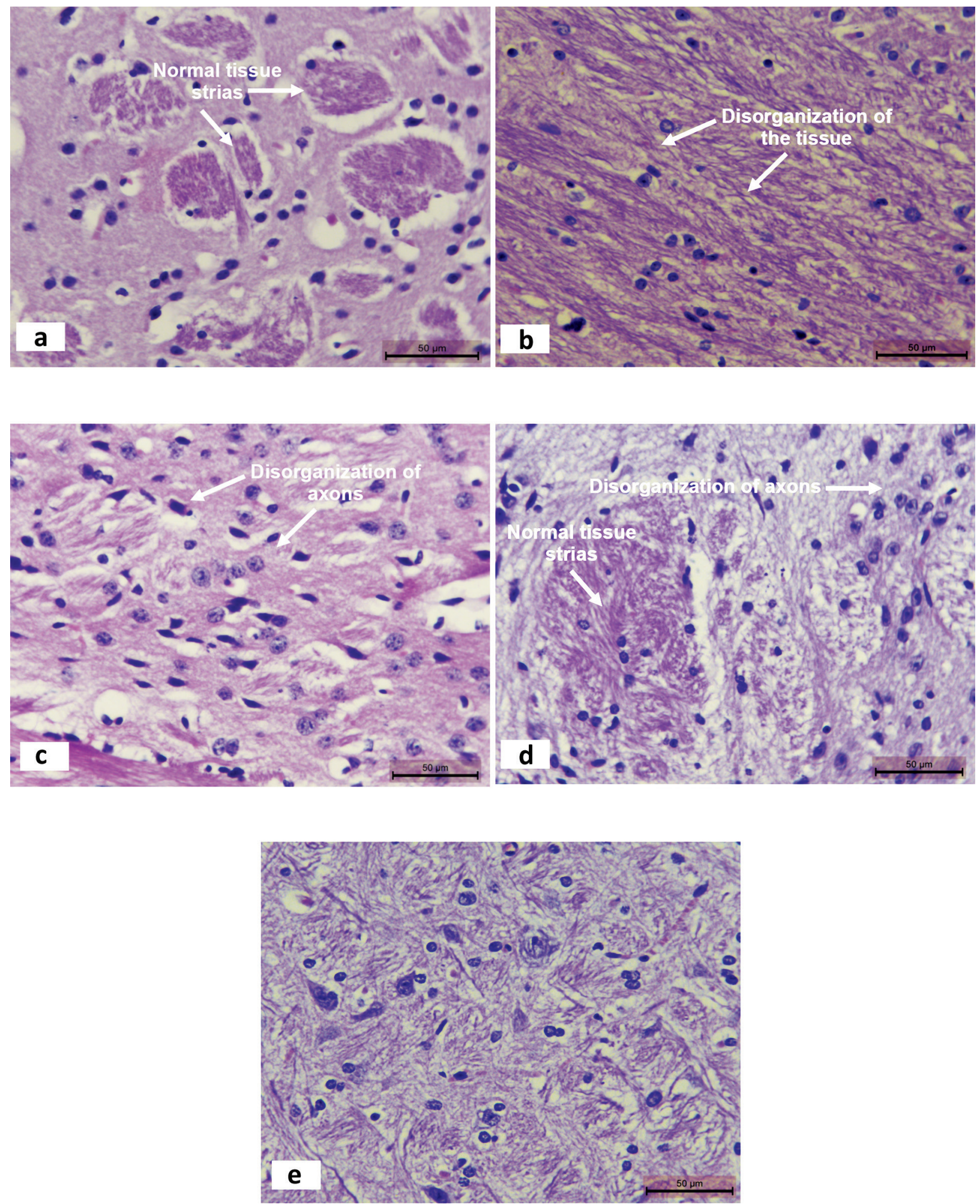

Figure 3 - Histological analyzes in the striatum of mice intraperitoneally treated with a fraction with casearins extracted from Casearia sylvestris leaves at doses of 2.5 (b), 5 (c), 10 (d) and $25 \mathrm{mg} / \mathrm{kg} /$ day (e) during 7 days. Negative control (a) received DMSO 4\%. Hematoxylin-eosin staining. Magnification, 400x. Scale bar $=50 \mu \mathrm{M}$. 
In liver examinations, vascular congestion and hydropic degeneration were more apparent in untreated and treated animals with FC 2.5, 5 and $25 \mathrm{mg} / \mathrm{kg} /$ day (Fig. 4a, 4b, 4d and 4e, respectively). Slight perivascular infiltration associated with necrosis was detected only at dose of $2.5 \mathrm{mg} / \mathrm{kg} /$ day (Fig. 4b). Minor hyperplasia of Kupper cells was noted in all groups.

\section{DISCUSSION}

Oxidation is chemically defined as the transfer of electrons between atoms. This phenomenon is naturally present in the metabolic processes of human cells that can be exacerbated by pro-oxidant substances or free radicals that cause oxidative damage. Free radicals are mainly produced in cytoplasmic organelles and are involved in biochemical reactions, energy production, phagocytosis and intracellular signaling. However, an excess of them cause deleterious effects on DNA, proteins, lipids and cell membranes leading to deteriorating disorders collectively known as oxidative stress (Alves et al. 2010, López-Alarcón and Denicola 2013).

Plants habitually have terpenes, allelopathic substances with high lipophilicity that act in protection against pathogens and herbivores. Studies with antioxidants present in fruits, vegetables and aerial parts of medicinal plants gained prominence in the scientific sphere due to the relationship between free radicals and etiology of chronic diseases as proliferative and neurodegenerative disorders (Rahman 2007, Freitas 2009, Farias et al. 2013, López-Alarcón and Denicola 2013).

In vitro antioxidant activity is mainly based on chemical assays that assess the ability of a substance to reduce the concentration of free radicals in a specific reaction medium (Van Den Berg et al. 1999, Menezes et al. 2004, Badarinath et al. 2010). Herein, the proposed method to determine the in vitro scavenging action of the nitrite ion, as described above, was based on the decomposition of SNP in nitric oxide at physiological $\mathrm{pH}$, under aerobic conditions, which produce nitrites. The FC reduced RNS levels with efficiency higher than the aqueous extract from Morinda citrifolia Linnaeus (Rubiaceae), a species with wide distribution in Brazilian traditional medicine and regionally known as "noni" (Serafini et al. 2011). Formerly, the hexane extract of stem and root barks of C. sylvestris showed immunomodulatory ability through the in vitro inhibition of nitric oxide production (NO) by macrophages (94.4 and $97.1 \%$, respectively) at 50 $\mu \mathrm{g} / \mathrm{mL}$ (Napolitano et al. 2005). It was important to perform the evaluation of FC against RNS, since these radicals may cause damage to biological components such as the aromatic amino acid tyrosine and DNA bases, particularly in guanines, by nitration or hydroxylation (Carocho and Ferreira 2012, Alam et al. 2013).

Hydroxyl radical is a very harmful, extremely reactive ROS, that is hardly scavenged in vivo. It interacts with different nonspecific cellular targets and may attack DNA, proteins, lipids and membrane organelles such as mitochondria, causing cellular breakdown (Anderson and Phillips 1999, Halliwell 2011). In vitro evaluation of the FC activity against hydroxyl radical was carried out by Fenton reaction, in which radical production occurs from the reaction between hydrogen peroxide and a transition metal such as iron or copper, producing radicals that react with 2-deoxyribose, whose degradation can be spectrophotometrycally determined. Antioxidants, like FC, can compete with 2-deoxyribose by free radicals causing a reduction in its degradation (Alves et al. 2010). Studies of the properties of Stachytarpheta angustifolia V., an African medicinal plant that improves the condition of HIV positive patients by reducing oxidative stress caused by the infection, possesses lower antioxidant capacity against hydroxyl radical $\left(\mathrm{EC}_{50}\right.$ of $99.4 \mu \mathrm{g} / \mathrm{mL}$ ) when compared to the $\mathrm{FC}$ $(6.4 \mu \mathrm{g} / \mathrm{mL})$, emphasizing the therapeutic potential of C. sylvestris substances (Awah et al. 2010). 

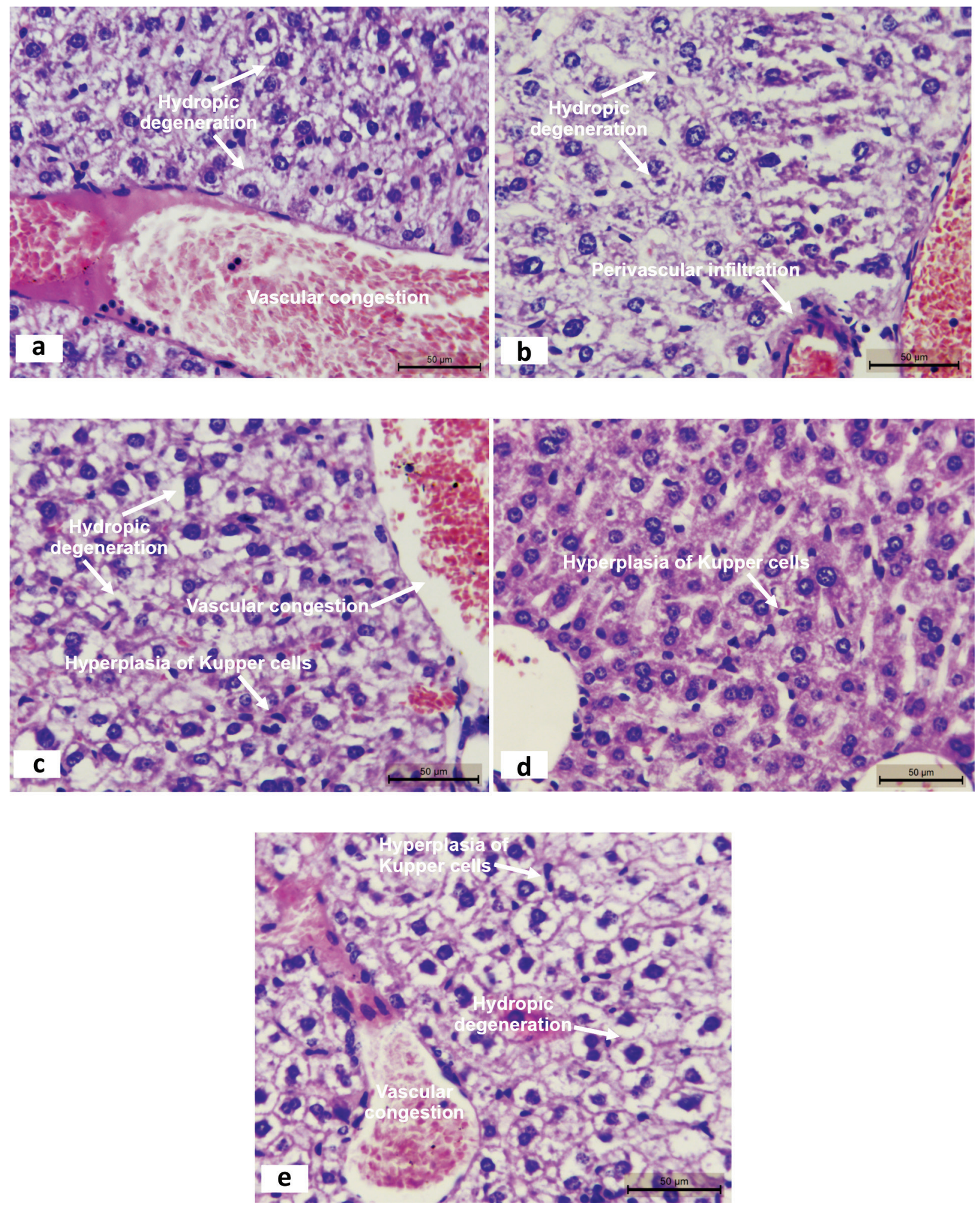

Figure 4 - Histological analyzes in liver of mice intraperitoneally treated with a fraction with casearins extracted from Casearia sylvestris leaves at doses of 2.5 (b), 5 (c), 10 (d) and $25 \mathrm{mg} / \mathrm{kg}$ /day (e) during 7 days. Negative control (a) received DMSO $4 \%$. Hematoxylin-eosin staining. Magnification, 400x. Scale bar $=50 \mu \mathrm{M}$. 
An alternative way to analyze oxidative stress is achieved by quantification of lipid peroxidation. The lipid radical is unstable and degrades very rapidly into secondary products. Most of them are electrophilic aldehydes, such as MDA, which is the main marker of oxidative injury in the unsaturated lipids in cell membranes, leading to oxidation of fatty acids (LH) and the formation of the lipid radical $(L \bullet)($ Reed 2011).

FC revealed potent capacity of reaction with TBARS $\left(\mathrm{EC}_{50}\right.$ of $0.16 \mu \mathrm{g} / \mathrm{mL}$ ), since it reduced lipid peroxidation in higher levels than those seen with carvacrol, an effective antioxidant phenolic monoterpene with anti-inflammatory properties present in Labiatae species (Guimarães et al. 2010, López-Alarcón and Denicola 2013).

Based on these results, it was possible to suggest four mechanisms for the antioxidant action of FC against the production of nitrite, hydroxyl radical and lipid peroxidation, taking into consideration the chemical structure of the casearins (Fig. 5). Most of the compounds found in the FC are represented by a series of oxygenated tricyclic cis-clerodane diterpenes, in which the tetrahydrofuran ring is $\mathrm{C}$-acylated at positions $\mathrm{C}-18$ and C-19 (Wang et al. 2009, Santos et al. 2010, Ferreira et al. 2011). Allylic hydrogens adjacent to double bonds at positions 2, 11, 16 and 18 possibly interact with radicals. Thus, atomic hydrogen is often removed from casearins, eradicating inert substances such as water, nitrous acid $\left(\mathrm{HNO}_{2}\right)$ and fatty acid and generating carbon stabilized radicals with the clerodane ditepernes, which might blockade oxidative damage and preserve biomolecules exposed to oxidative radicals (LópezAlarcón and Denicola 2013).
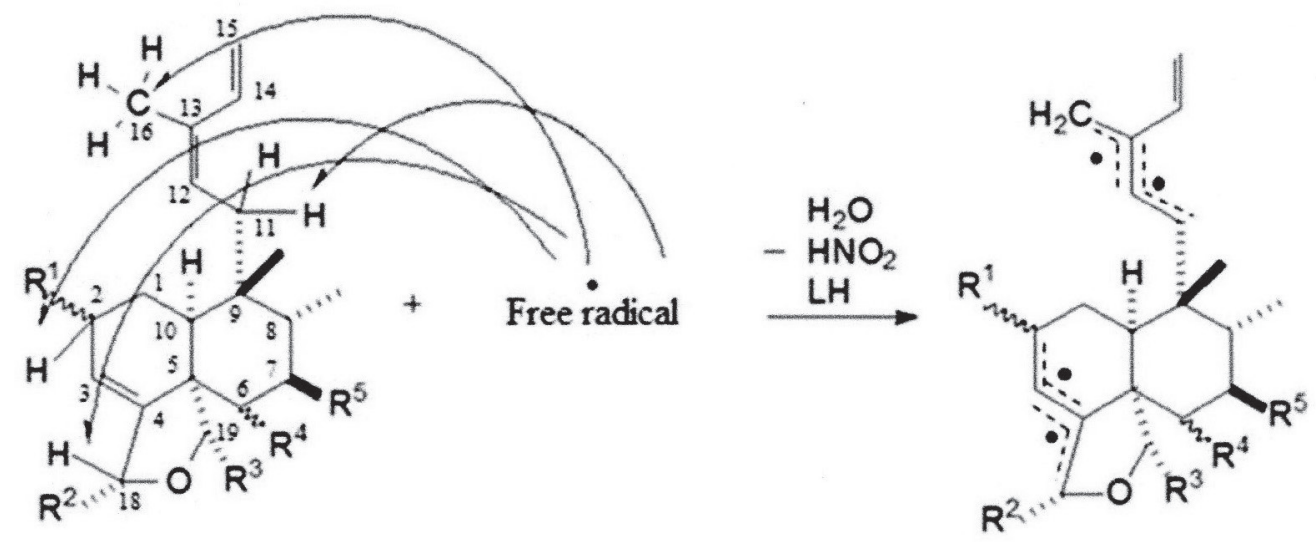

Figure 5 - Plausible mechanisms of the in vitro antioxidant action on the nitrite radical formation of a fraction with casearins extracted from Casearia sylvestris leaves and based on the skeleton of the casearins.

In fact, the antioxidant potential of distinct Casearia species was also shown using two of the most common radical scavenging assays [TBARS and 1,1-diphenyl-2-picrylhydrazyl (DPPH)]. Among all bioactive compounds found in the ethanolic extract of $C$. sylvestris, the therapeutic effects of essential oils have been attributed to the biciclogermacrene, a sesquiterpene with anti-inflammatory activity
(Menezes et al. 2004, Mosaddick et al. 2004, Ferreira et al. 2011).

In spite of plausible evidences about in vitro antioxidant action of the FC, these discoveries do not guarantee the maintenance of the FC redox potential in organic systems. The antioxidant activity of a substance depends not only on its chemical reactivity, but also on its interaction with 
organic molecules and the impact that biological environments exert upon it. In addition, solubility, concentration and complexity of the plant constituents are factors that can be modified within the organism, altering its antioxidant potential (Alves et al. 2010, Halliwell 2011).

All human tissues suffer oxidative damage, but the brain cells do not divide and their metabolism is very dependent on oxygen, glucosis and ATP to maintain normal physiology. Furthermore, the presence of oxidizable ions and neurotransmitters favor cell damage. Thus, the evaluation of the antioxidant activity of natural products such as casearins becomes especially important in tissue and organs more vulnerable to oxidative stress, like the brain (Barbosa et al. 2006, Pala and Gurkan 2008). In relation to C. sylvestris compounds, these analyses are also critical since they have chemotherapeutic potential (Ferreira et al. 2010, Santos et al. 2010, Ferreira et al. 2011, Prieto et al. 2013, Ferreira et al. 2014) and many cancer patients fail chemotherapy because of undesired side effects, in which liver and brain tissues are frequently targets of oxidative stress and chemotherapeutic toxicity (Williams et al. 2002). Then, in vivo studies were also performed to visualize protection by the FC against generation of free radicals in complex systems.

In vivo outcomes of the hippocampus and striatum suggest that the FC presents scavenger activity in a concentration dependent way, except in relation to TBARS and nitrite levels, since antioxidant action was not found for these two analytes. Brain GSH prolife of the animals exhibited similar absence of antioxidant potential. GSH is an antioxidant substance primarily found in the liver, brain and kidneys that contribute towards maintaining the activity of exogenous antioxidants such as AA and tocopherol. It is constituted by the peptides glycine, cysteine and glutamic acid, which contribute to reduce peroxide content when oxidized by glutathione peroxidase (GPx). In the nervous system, it can also act as a neurotransmitter via
NMDA (N-methyl-D-aspartate). Consequently, its assessment in the central nervous system is extremely relevant, since there is not enzymatic defense upon hydroxyl radical (Carocho and Ferreira 2012).

Catalase is an additional enzymatic defense against ROS. In nervous tissues there are typically low levels of catalase, and its evaluation is important due to oxidative metabolism and intense free radicals' generation, showing a more specific protection against $\mathrm{H}_{2} \mathrm{O}_{2}$ produced under pathological conditions (Shim et al. 2003, Barbosa et al. 2006). Catalase activity showed dose dependent results in both hippocampus and striatum areas, indicating that doses higher than $25 \mathrm{mg} / \mathrm{kg}$ could overcome AA in the modulation of the enzyme. It is possible that this increase represents improvement in combating oxidative stress. Further studies with higher doses are in progress to confirm it. Indeed, the antioxidant enzymes SOD and catalase, by virtue of their ability to catalyze the disproportionation reactions of their substrates superoxide radical and hydrogen peroxide, respectively, have an enormous theoretical advantage over exogenous antioxidants that are stoichiometrically consumed. There are published reports of at least 30 different botanical extracts or purified phytochemicals that when ingested by mammals result in increased activities of SOD and catalase, with concomitant decreases in plasma TBARS, indicative of decreased lipid peroxidation, which has come to be synonymous with decreased oxidative stress. It is assumed that these substances act primarily by direct induction of SOD and catalase and that this results in decreased oxidative stress (Nelson et al. 2006).

In vitro assessments are performed under controlled conditions such as temperature, $\mathrm{pH}$, well-defined substrates concentrations and ideal reaction medium, basically depending on the intrinsic chemical properties of the new substance. Therefore, failure to maintain the in vivo antioxidant property of the FC is probably associtated with the complexity of organic systems and/or as a result of biotransformation into products with lower 
antioxidant potential (Anderson and Phillips 1999, Alves 2010). This biotransformation commonly occurs in the liver, the main organ in the body able to metabolize xenobiotics compounds, converting them into inactive substances and facilitating their excretion throught the kidneys (urine) or bile (feces). Diminution in GSH levels suggests that FC may also interfere in the process of detoxification activated by glutathione S-transferase (Williams et al. 2002, Pugh et al. 2009).

Because polyunsaturated fatty acids are easy targets for oxidants, and since the process of lipid peroxidation is, once initiated, a self-sustaining free radical chain process, the accumulation of lipid peroxidation products provides the most common biochemical marker of oxidative stress. There is strong correlation between thiobarbituric acid-reactive substances (TBARS) as a marker of lipid peroxidation and products that reflect oxidative damage to DNA (Chen et al. 2005, Avila-Nava et al. 2014). However, in normal healthy men who have low intake of fruits and vegetables, and who might be further stressed by smoking, and who have measurable levels of oxidative stress, a moderate supplement of vitamins E, C, and folic acid, produced no alteration in measures of oxidant damage (Jacob et al. 2003). Similarly, studies that have used supplementation with a concentrate of fruits and vegetables (Van Den Berg et al. 2001) or the daily intake of $600 \mathrm{~g}$ of fruits and vegetables (Moller et al. 2003) have produced no effects on markers of oxidative damage to lipids or DNA. Thus, reasonable intakes or administration of exogenous stoichiometric scavengers of oxidants habitually fail to inhibit lipid peroxidation, corroborating, partly, with outcomes found in in vivo studies performed with FC and demonstrating how difficult is to prove the antioxidant potentiality of bioactive substances in complexe organisms.

Thus, histological analyse revealed lesions on hippocampus and striatum areas at lower doses (2.5 and $5 \mathrm{mg} / \mathrm{kg}$ ) such as nuclear vacuolation, fragmentation of nuclear chromatin and hyper- chromasia of nuclear material suggestive of cell death, while these changes were partially reversed at higher doses (10 and $25 \mathrm{mg} / \mathrm{kg}$ ). Likely, these findings (reduction in TBARS levels at lower doses and increase of nitrite content) should be related to the down modulation of enzymatic defenses, justifying more harmful consequences (Krishnaiah et al. 2011).

With the exception of the reduction of TBARS formation, FC displayed only in vitro antioxidant activity. These findings indicate that biotransformation into metabolites with lower antioxidant capacity can be responsible by negative results in animals, which probably involve the liver basic machinery and its biochemical processes such as oxidation and hidroxilation in absence of hepatic injury. Interestingly, FC-treated animals exhibited alterations indicative of neurotoxicity, indicating the need for precaution regarding the consumption of medicinal formulations based on C. sylvestris.

\section{ACKNOWLEDGMENTS}

We wish to thank Conselho Nacional de Desenvolvimento Científico e Tecnológico (CNPq, process 484286/2011-0) and Fundação de Amparo à Pesquisa do Estado do Piauí (FAPEPI, process 034/2012-PPP) for financial support in the form of grants.

\section{RESUMO}

Casearia sylvestris Swartz é uma planta medicinal amplamente distribuída no Brasil. Ela possui atividade anti-inflamatória, antiulcerogênica e antitumoral e é popularmente utilizada para tratar envenenamentos ofídicos, ferimentos, diarreia, gripes e resfriados. Suas folhas são ricas em diterpenos clerodânicos tricíclicos oxigenados, particularmente casearinas. Aqui, nós avaliamos as atividades antioxidantes de um fração com casearinas (FC) isolada de C. sylvestris e as alterações histológicas no sistema nervoso central e fígados de camundongos Mus musculus. Primeiramente, estudos in vitro $(0,9,1,8,3,6,5,4$ e 
7,2 $\mu \mathrm{g} / \mathrm{mL}$ ) revelaram valores de $\mathrm{CE}_{50}$ de 3,7, 6,4 e 0,16 $\mu \mathrm{g} / \mathrm{mL}$ para nitrito, radical hidroxila e níveis de TBARS, respectivamente. Em seguida, a FC (2,5, 5, 10 e $25 \mathrm{mg} /$ $\mathrm{kg} / \mathrm{dia}$ ) foi administrada intraperitonealmente por 7 dias consecutivos em camundongos Swiss. Os níveis de nitrito no hipocampo $(26,2,27,3,30,2$ e $26,6 \mu \mathrm{M})$ e no corpo estriado $(26,3,25,4,34,3$ e 27,5 $\mu \mathrm{M})$ aumentaram em todos os animais tratados com a FC $(\mathrm{P}<0.05)$. As menores doses reduziram os níveis de glutationa reduzida, de catalase e de TBARS no hipocampo e no corpo estriado. Com exceção da redução na formação de TBARS, a FC demonstrou atividade antioxidante apenas in vitro. Os animais exibiram alterações histológicas que sugerem neurotoxicidade e hepatotoxicidade, indicando a necessidade de cuidados em relação ao consumo de preparações medicinais à base de Casearia sylvestris.

Palavras-chave: Diterpenos clerodânicos, Casearia sylvetris, antioxidante, alterações morfológicas, toxicidade.

\section{REFERENCES}

Aboin E, Arquero P ANd BalboA V. 1987. Prostaglandina PGE, análogo sintético misoprostol no manuseio de lesões de mucosa gástrica induzidas por etanol. Arq Bras Med Vet Zootec 61: 277-283.

ALAM MN, BRISTI NJ AND RAFIQUZZAMAN M. 2013. Review on in vivo and in vitro methods evaluation of antioxidant activity. Saudi Pharm J 21: 143-152.

ALVES CQ, DAVID JM, DAVID JP, BAHIA MV AND AGUIAR RM. 2010. Métodos para determinação de atividade antioxidante in vitro em substratos orgânicos. Quim Nova 33: 22022210.

ANDERSON D AND PHILLIPS BJ. 1999. Comparative in vitro and in vivo effects of antioxidants. Food Chem Toxicol 37: 1015-1025.

Avila-Nava A, Calderón-Oliver M, Medina-Campos ON, Zou T, Gu L, TORres N, Tovar AR AND PedrazACHAVERRI J. 2014. Extract of cactus (Opuntia ficus indica) cladodes scavenges reactive oxygen species in vitro and enhances plasma antioxidant capacity in humans. J Func Foods 10: 13-24.

AWAH FM, UZOEGWU PN, OYUGI JO, RUTHERFORD J, IFEONU P, YAO XJ, FOWKE KR AND EZE MO. 2010. Free radical scavenging activity and immunomodulatory effect of Stachytarpheta angustifolia leaf extract. Food Chem 119: 1409-1416.

BADARINATH AV, RAO KM, CHETTY CMS, RAMKANTH S, RAJAN TVS AND GNANAPRAKASH K. 2010. A review on invitro antioxidant methods: comparisions, correlations and considerations. Int J PharmTech Res 2: 1276-1285.
Barbosa LF, Medeiros MHG And Augusto O. 2006. Danos oxidativos e neurodegeneração: o que aprendemos com animais transgênicos e nocautes? Quim Nova 29: 13521360.

BAsile AC, SERTí́ JAA, PANIZZA S, Oshiro TT AND AZzolini CA. 1990. Pharmacological assay of Casearia sylvestris. I: Preventive anti-ulcer activity and toxicity of the leaf crude extract. J Ethnopharmacol 30: 185-197.

BASU S AND HAZRA B. 2006. Evaluation of nitric oxide scavenging activity, in vitro and ex vivo, of selected medicinal plants traditionally used in inflammatory diseases. Phytother Res 20: 896-900.

Borges MH, SoAres AM, Rodrigues VM, Oliveira F, FranSHECHI AM, RUCAVAdO A, GIGLIO JR AND HoMSIBRANDEBURGO MI. 2001. Neutralization of proteases from bothrops snake venoms by the aqueous extract from Casearia Sylvestris (Flacourtiaceae). Toxicon 39: 1863-1869.

Borges MH, SOARES AM, RODRIGUES VM, QUINTERO A, Lizano S, Gutiérrez JM, Giglio JR AND HomsiBRANDEBURGO MI. 2000. Effects of aqueous extract of Casearia sylvestris (Flacourtiaceae) on actions of snake and bee venoms and on activity of phospholipases A2. Comp Biochem Physiol 127: 21-30.

CAmpêlo LML, Almeida AAC, Freitas RLM, Cerqueira GS, Sousa GF, Saldanha GB, FeItosa CM And Freitas RM. 2011. Antioxidant and antinociceptive effects of Citrus limon essential oil in mice. J Biomed Biotechnol 2011: 1-8.

CAROCHO M AND FERREIRA ICFR. 2012. A review on antioxidants, prooxidants and related controversy: Natural and synthetic compounds, screening and analysis methodologies and future perspectives. Food Chem Toxicol 51: 15-25.

Carvalho PRF, Furlan M, Young MCM, Kingston DGI AND BolZANI VS. 1998. Acetylated DNA-damaging clerodane diterpenes from Casearia sylvestris. Phytochem 49: 1659-1662.

Cavalcante Wlg, Camposa TO, Pai-Silva MD, Pereira OS, Oliveira CZ, SoARes AM AND Gallacci M. 2007. Neutralization of snake venom phospholipase A2 toxins by aqueous extract of Casearia sylvestris (Flacourtiaceae) in mouse neuromuscular preparation. J Ethnopharmacol 112: 490-497.

Chance B AND Maehly AC. 1955. Assay catalases and peroxidases. Method Enzymol 2: 764-768.

Chen HJ, Wu CF AND HuANG JL. 2005. Measurement of urinary excretion of 5-hydroxymethyluracil in human by GC/NICI/MS: correlation with cigarette smoking, urinary TBARS and etheno DNA adduct. Toxicol Lett 155: 403-410.

Claudino JC, Sacramento LVS, Koch I, Santos Ha, Cavalheiro AJ, Tininis AG And Santos AG. 2013. Evaluation of morpho-anatomical and chemical differences between varieties of the medicinal plant Casearia sylvestris Swartz. An Acad Bras Cienc 85: 1253-1265. 
DA SILVA SL, CHAAR JS AND YANO T. 2009. Chemotherapeutic potential of two gallic acid derivative compounds from leaves of Casearia sylvestris Sw (Facourtiaceae). Eur J Pharmacol 608: 76-83.

DRAPER HH AND HADlEY M. 1990. Malondialdehyde determination as an index of lipid peroxidation. Method Enzymol 186: 421-431.

EEC DiReCTIVE OF 1986. Council Directive of 24 November 1986 on the approximation of laws, regulations and administrative provisions of the Member States regarding the protection of animals used for experimental and other scientific purposes (86/609/EEC), $7 \mathrm{p}$.

EsterbaUer H AND CHEESEMAN KH. 1990. Determination of aldehydic lipid peroxidation products: malonaldehyde and 4-hydroxynonenal. Method Enzymol 186: 407-421.

ESTEVES I ET AL. 2005. Gastric anti-ulcer and anti-inflammatory activities of the essential oil from Casearia sylvestris Sw. J Ethnorpharmacol 101: 191-196.

FARias DF, SOUZA TM, Viana MP, SOARES BM, CUNHA AP, VASCONCELOS IM, RICARDO NMPS, FERREIRA PMP, Melo VMM AND CARVALHO AFU. 2013. Antibacterial, antioxidant, and anticholinesterase activities of plant seed extracts from Brazilian semiarid region. BioMed Res Int 2013: 1-9.

Ferreira PMP, Costa-Lotufo LV, Moraes MO, Barros FWA, MARTINS AMA, CAVALHEIRO AJ, BOLZANI VS, SAntos AG And Pessoa C. 2011. Folk uses and pharmacological properties of Casearia sylvestris: a medicinal review. An Acad Bras Cienc 83: 1373-1384.

Ferreira PMP, Militão GCG, Lima DJB, Costa NDJ, Machado KC, Santos AG, Cavalheiro AJ, Bolzani VS, Silva DHS AND PESSOA C. 2014. Morphological and biochemical alterations activated by antitumor clerodane diterpenes. Chem-Biol Interact 222: 112-125.

FERreira PMP, SANTOS AG, TININIS AG, Costa PM, Cavalheiro AJ, Bolzani VS, Moraes mo, CostaLotufo LV, Montenegro RC And Pessoa C. 2010. Casearin X exhibits cytotoxic effects in leukemia cells triggered by apoptosis. Chem-Biol Interact 188: 497-504.

FREITAS RM. 2009. The evaluation of effects of lipoic acid on the lipid peroxidation, nitrite formation and antioxidant enzymes in the hippocampus of rats after pilocarpineinduced seizures. Neurosci Lett 455: 140-144.

GREEN LC, TANNENBAUM SR AND GOLDMAN P. 1981. Nitrate synthesis in the germfree and conventional rat. Science 212: $56-58$.

Guimarães AG ET AL. 2010. Bioassay-guided evaluation of antioxidant and antinociceptive activities of carvacrol. Basic Clin Pharmacol Toxicol 107: 949-957.

HALliwell B. 2011. Free radicals and antioxidants - quo vadis? Trends Pharmacol Sci 32: 125-130.

ITOKAWA H, TOTSUKA N, MORITA HN, TAKEYA K, IITAKA Y, SCHENKEL EP AND MONTIDOME M. 1990. New antitumor Principles, Casearins A-F, from Casearia sylvestris Sw. (Flacourtiaceae). Chem Pharm Bull 38: 3384-3388.
Jacob RA, Aiello GM, Stephensen CB, Blumberg JB, Milbury PE, WALlock LM AND AMES BN. 2003. Moderate antioxidant supplementation has no effect on biomarkers of oxidant damage in healthy men with low fruit and vegetable intakes. J Nutr 133: 740-743.

KRISHNAIAH D, SARBATLY R AND NithyANANDAM R. 2011 A review of the antioxidant potential of medicinal plant species. Food Bioprod Process 89: 217-233.

Kumbhare MR, Guleha V AND Sivakumar T. 2012 Estimation of total phenolic content, cytotoxicity and in vitro antioxidant activity of stem bark of Moringa oleifera. Asian Pac J Trop Dis 2: 144-150.

LOPES GKB, SCHULMAN HM AND LiMA MH. 1999. Polyphenol tannic acid inhibits hydroxyl radical formation from Fenton reaction by complexing ferrous ions. Biochim Biophys Acta 1472: 142-152.

LÓPEZ-ALARCÓN C AND DENICOLA A. 2013. Evaluating the antioxidant capacity of natural products: A review on chemical and cellular-based assays. Anal Chim Acta 763: 1-10.

LOWRY H, Rosebrough NJ, FARR AL AND RANDALL RJ. 1951. Protein measurements with the folin phenol reagent. JOBC 193: 265-275.

Menezes PR, Schwarz EA AND SANTOS CAM. 2004. In vitro antioxidant activity of species collected in Paraná. Fitoterapia 75: 398-400.

Mesquita ML, Grellier P, Mambu L, De Paula Je and ESPÍNDOLA LS. 2007. In vitro antiplasmodial activity of Brazilian Cerrado plants used as traditional remedies. J Ethnopharmacol 110: 165-170.

Moller P, Vogel V, Pedersen A, Dragsted LO, SANDSTROM B AND LOFT S. 2003. No effect of 600 grams fruit and vegetables per day on oxidative DNA damage and repair in healthy nonsmokers. Cancer Epidemiol Biomarkers Prev 12: 1016-1022.

Morita H, NaKayama M, KoJima H, TaKeya K, ItoKawa H, SCHENKEL EP AND Motidome M. 1991. Structure and cytotoxic activity relationship of casearins, new clerodane diterpenes from Casearia sylvestris Sw. Chem Pharm Bull 39: 693-697.

MOSADDICK MA, BANBURY L, FORSTER P, BOOTH R, MARKHAM J, LEACH D AND WATERMAN PG. 2004. Screening of some Australian Flacourtiaceae species for in vitro antioxidant, cytotoxic and antimicrobial activity. Phytomed 11: 461-466.

NAPOLITANO DR, Mineo JR, SOUZA MA, PAULA JE, ESPINDOLA LS AND ESPINDOLA FS. 2005. Down-modulation of nitric oxide production in murine macrophages treated with crude plant extracts from the Brazilian Cerrado. J Ethnopharmacol 99: 35-41.

Nelson SK, Bose SK, Grunwald GK, Myhill P AND MCCORD JM. 2006. The induction of human superoxide dismutase and catalase in vivo: a fundamentally new approach to antioxidant therapy. Free Radical Bio Med 40: 341-347.

OBERLIES NH ET AL. 2002. Novel bioactive clerodane diterpenoids from the leavesand twigs of Casearia sylvestris. J Nat Prod 65: 95-99. 
PALA FS AND GURKAN H. 2008. The role of free radicals in ethiopathogenesis of diseases. Advances in Molecular and Cell Biol 1: 1-9.

PAXINOS G AND WATSON C. 1986. The brain in stereotaxic coordinates. New York: Academic Press, 242 p.

Prieto AM, Dos Santos AG, Oliveira AP, CAVAlheiro AJ, Silva DH, Bolzani VS, VARANDA EA AND SOARES CP. 2013. Assessment of the chemopreventive effect of casearin B, a clerodanediterpene extracted from Casearia sylvestris (Salicaceae). Food Chem Toxicol 53: 153-159.

Pugh AJ, BARVE AJ, FAlKNer K, PATEl M AND MCClain CJ. 2009. Drug- induced hepatotoxicity or drug- induced liver injury. Clin Liver Dis 13: 277-294.

RAHMAN K. 2007. Studies on free radicals, antioxidants, and co-factors. J Clin Interv Aging 2: 219-236.

Reanmongkol W, Matsumoto $\mathrm{K}$, Watanabe $\mathrm{H}$, SUBHADHIRASAKUL S AND SAKAI SI. 1994. Antinociceptive and antipyretic effects of alkaloids extracted from the stem bark of Hunteria zeylanica. Biol Pharm Bull 17: 1345-1350.

REED TT. 2011. Lipid peroxidation and neurodegenerative disease. Free Radical Bio Med 51: 1302-1319.

SANTOS AG, FERreira PMP, VIEIRA-JÚNIOR GM, PEREZ CC, Tininis AG, Silva GH, Bolzani VS, Costa-Lotufo LV, Pessoa C AND CAVAlheiro AJ. 2010. Casearin X, its degradation product and other clerodanediterpenes from leaves of Casearia sylvestris: evaluation of cytotoxicity against normal and tumour human cells. Chem Biodivers 7: 205-215.

SEDLAK J AND LINSAY RH. 1988. Estimation of protein bound and nonproteinsolfhydril groups in tissues with Ellman's reagent. Anal Biochem 25: 192-205.

SERAFINI MR ET AL. 2011. Morinda citrifolia Linn leaf extract possesses antioxidant activities and reduces nociceptive behavior and leukocyte migration. J Med Food 14: 11591166.
ShIM IS, Momose Y, Yamamoto A, KIM DW AND USUI K. 2003. Inhibition of catalase activity by oxidative stress and its relationship to salicylic acid accumulation in plants. Plant Growth Regul 39: 285-292.

Silva AC, Balz D, De Souza JBD, Morsc VM, CORRÊA MC, ZANETTI GD, MANFRON MP AND SCHETINGER MRC. 2006. Inhibition of NTPDase, 50-nucleotidase, $\mathrm{Na}+\mathrm{K}+-$ ATPase and acetylcholinesterase activities by subchronic treatment with Casearia sylvestris. Phytomed 13: 509514.

TAIRA J, TSUChIDA E, KatOH MC, UEHARA Mand OGI T. 2015. Antioxidant capacity of betacyanins as radical scavengers for peroxyl radical and nitric oxide. Food Chem 2015 166: 531-536.

VAN DEN Berg R, HaEnen GRMN, VAN DEN BERG H AND BAST A. 1999. Applicability of an improved Trolox equivalent antioxidant capacity (TEAC) assay for evaluation of antioxidant capacity measurements of mixtures. Food Chem 66: 511-517.

VAN DEN Berg R, VAN Vliet T, BRoEkMans WM, CNUBBen NH, VAes WH, Roza L, HAENEN GR, BAST A AND VAN DEN BERG H. 2001. A vegetable/fruit concentrate with high antioxidant capacity has no effect on biomarkers of antioxidant status in male smokers. J Nutr 13: 1714-1722.

WANG W, ZHAO J, WANG YH, SMillie TA, Li XC AND KHAN IA. 2009. Diterpenoids from Casearia sylvestris. Planta Med 75: 1436-1441.

WILLIAMS DP, KITTERINGHAM NR, NAISBITT DJ, PIRMOHAMED M, SMITH DA AND PARK BK. 2002. Are chemically reactive metabolites responsible for adverse reactions to drugs? Curr Drug Metab 3: 351-366.

WATtenBerg LW. 1985. Chemoprevention of cancer. Cancer Res 45: 1-8. 
